\title{
THE VALUE OF COLPOSCOPY, HIGH RISK HPV-DNA AND HISTOPATHOLOGIC EXAMINATION IN THE MANAGEMENT OF ABNORMAL PAP SMEAR RESULTS
}

\author{
Vugar BAYRAMOV ${ }^{1}$, Yavuz Emre SUKUR ${ }^{2}$, Sevgi TEZCAN ${ }^{2}$ \\ 1 Merkezi Gümrük Hospital, Department of Obstetrics and Gynecology, Bakı, Azerbaijan \\ 2 Ankara University School of Medicine, Department of Obstetrics and Gynecology, Ankara, Turkey
}

\section{SUMMARY}

Objective: Pap smear test is a major screening test for early diagnosis and treatment of cervix cancer. The aim of our study was to assess the value of HPV-DNA, colposcopy and histopathologic examination in the management of patients with abnormal cervical cytology.

Materials and methods: This prospective cohort study was conducted in Ankara University Cebeci Hospital gynecology outpatient clinic. The study compromised 86 patients with smear results of ASCUS, AGC, L-SIL and H-SIL. Age, gravity, parity, age at first coitus, smoking status, number of partners, high risk HPV-DNA status and pathologic colposcopy findings were investigated.

Results: Mean age of the patients was 35 years and the most common abnormal smear result was ASCUS, with 55 patients (63\%). There was no significant difference between the groups regarding demographic characteristics except age at first coitus and pathologic colposcopy findings. Among patients diagnosed as ASCUS 34.5\% had been upgraded with histopathologic examination. Among patients diagnosed as L-SIL $73.6 \%$ had been down-graded with histopathologic examination. However, after the histopathologic exam of 9 H-SIL patients two (22.2\%) were diagnosed as CIN II, two (22.2\%) were diagnosed as CIN III and one (11.1\%) was diagnosed as cervical cancer. In the groups of ASCUS, L-SIL and H-SIL the presence of high risk HPV-DNA were 11\%, 5\% and 33\%, respectively.

Conclusion: If we are sure that the patient will attend the follow-up visits, then for the ones with ASCUS and L-SIL a repeat smear test would be the appropriate. However, in the management of patients with H-SIL colposcopic biopsy would be the best approach.

Key words: cervix cancer, colposcopy, high risk HPV, pap smear

Journal of Turkish Society of Obstetrics and Gynecology, (J Turk Soc Obstet Gynecol), 2011; Vol: 8 Issue: 4 Pages: 272- 8

Address for Correspondence: Dr. Vugar Bayramov. Merkezi Gümrük Hospital, Bakü, Azerbaijan Phone: 99(450) 4092244

e-mail: vugar.bayramov@gmail.com

Received: 21 May 2011, revised: 02 August 2011, accepted: 11 August 2011, online publication: 23 August 2011 


\section{ANORMAL PAP SMEAR SONUCU YÖNETIMINDE KOLPOSKOPİ, YÜKSEK RİSKLİ HPV-DNA VE HISTOPATOLOJIK İNCELEMENIN ÖNEMI}

\section{ÖZET}

Amaç: Pap smear testi serviks kanserinin erken tanı ve tedavisinde çok önemli bir tarama yöntemidir. Bu çalışmanın amacı, smear testinde anormallik saptanan olguların yönetiminde HPV-DNA, kolposkopi ve patolojik incelemenin öneminin belirlenebilmesidir.

Gereç ve yöntemler: Bu prospektif kohort çalışma 2005-2007 yılları arasında Ankara Üniversitesi Cebeci Hastanesi jinekoloji polikliniğinde yürütülmüşürr. Çalışmaya smear sonuçları ASCUS, AGC, L-SIL ve H-SIL olan 86 hasta dahil edilmiştir. Gruplarda yaş, gravida, parite, ilk koitus yaşı, sigara kullanım durumu, partner sayısı, yüksek riskli HPVDNA pozitifliği ve patolojik kolposkopi bulguları karşılaştırılmıştır.

Bulgular: Hastaların ortalama yaşı 35 ve en sık anormal smear sonucu 55 hastada (\%63) ASCUS'tur. Demografik özelliklerden sadece ilk koitus yaşı ve patolojik kolposkopi bulguları açısından gruplar arasında fark saptanmıştır. ASCUS saptanan hastaların \%34.5'inde patolojik inceleme ile daha ileri bir tanı izlenmiştir. L-SIL saptanan hastaların ise \%73.6'sında daha basit bir tanıya gerileme izlenmiştir. Dokuz H-SIL hastasının ise ikisinde (\%22.2) CIN II, ikisinde (\%22.2) CIN III ve birinde (\%11.1) serviks kanseri izlenmiştir. ASCUS, L-SIL ve H-SIL gruplarında yüksek riskli HPV-DNA pozitfliği sırasıyla \%11,\%5 ve \%33 olarak tespit edilmiștir.

Sonuç: Pap smear testinde ASCUS ve L-SIL saptandiğında ĕger hasta uyumundan eminsek yönetimde smear tekrarl ile takip uygundur. H-SIL saptanan hastalarda kolposkopik biyopsi uygun yaklaşım olacaktır.

Anahtar kelimeler: kolposkopi, pap smear, serviks kanseri, yüksek riskli HPV

Türk Jinekoloji ve Obstetrik Derneği Dergisi, (J Turk Soc Obstet Gynecol), 2011; Cilt: 8 Sayl: 4 Sayfa: 272- 8

\section{INTRODUCTION}

Globally, cervical cancer is still one of the most important cancers with the incidence of $1 / 500.000^{(1)}$. Incidence and mortality in cervical cancer have decreased among the last 50 years with the widespread use of Papanicolaou (Pap) smear test, but not eliminated yet ${ }^{(2-4)}$. Detection of precancerous lesions has increased significantly with the use of cytological Pap smear screening; however, management of these abnormal results has raised concern. Approximately, $5 \%$ of Pap smear screening test results is abnormal ${ }^{(5)}$. Although the management of high grade lesions is clear, there's still controversy about the management of low grade lesions. Although the impact of the treatment of low grade lesions is not well known yet, there are still controversies about the necessity and cost-effectiveness of invasive methods like colposcopy and biopsy $(5,6)$.

Since the development of Bethesda System in 1989, a new terminology has come out for cervical pathologies (7). However, the Bethesda System was revised in 2001
(8). Generally, 2-3\% of Pap smear tests are diagnosed as L-SIL and $0,6 \%$ diagnosed as H-SIL ${ }^{(9)}$. The prevalence of ASCUS is more arbitrary, because it represents a poorly defined fraction of the previous expansive "benign atypia" or "Pap Class 2" classification. In the United States, more than 2 million Pap tests per year are interpreted as ASCUS(10). Although some management algorithms have been developed for cervical pathologies, no universal agreement exists on managing ASCUS and L-SIL.

The aim of this study was to investigate the clinical importance of colposcopy, high risk HPV-DNA test and histopathological examination in patients with abnormal Pap-smear test results and to determine the patients with increased risk for preinvasive and invasive neoplasia. 


\section{MATERIALS AND METHODS}

The study was conducted in Ankara University Cebeci Hospital Department of Obstetrics and Gynecology between 2005 and 2007. The prospective cohort trial invited all women aged 20-60 and diagnosed with abnormal pap smear result in the outpatients clinic. Patients are classified according to Pap smear test results; atypical squamous cells of undetermined significance (ASCUS), low grade intraepithelial lesion (L-SIL), and high grade intraepithelial lesion (H-SIL). The study was approved by the Institutional Review Board of the University and written informed consent was obtained from all patients before entering the study.

Demographic parameters like age, gravity, parity, number of sexual partners, age at first coitus and smoking status were interrogated for all patients with abnormal Pap smear results who were included in the study. Colposcopy was performed for all participants and pathological colposcopy findings were recorded. Colposcopy examinations were performed by WelchAllyn video path VLX-10 device which had 40x magnification and green filter. At colposcopic examination first the cervix was cleaned by $0,9 \%$ saline solution and visualized at low magnification and pathologies of vasculature are investigated under green filter. Then 3-5\% acetic acid was applied and after waiting 60 seconds cervix was visualized under low and high magnification. Aceto-white areas and atypical vasculature are determined. Iodine negative areas are determined at cervix by applying lugol solution. A biopsy was performed from aceto-white, mosaic, iodine negative areas and from punctuations, atypical vasculatures, and erosions. When these pathological findings were not determined a blind punch biopsy was performed from four quadrants of cervix and biopsy specimens were transferred to pathology laboratory inside formol.

High risk HPV-DNA was investigated in cervical swaps of all participants. The presence of high risk HPV-DNA was evaluated by Hybrid Capture 2 (Qiagen Corporation, Gaithersburg, Maryland, USA) in cervical specimens obtained by ThinPrep (Hologic, Marlborough, Massachusetts, USA) in the Department of Medical Genetics. Hybride Capture 2 testing was performed according to the manufacturer's instructions by using high risk HPV kit. By this way 13 different HPV types $(16,18,31,33,35,39,45,51,52,56,58$,
59, and 68) were evaluated. Cytological evaluations were performed by a gynecologic cyto-pathologist. Biopsies were evaluated by a gynecologic pathologist Colposcopic evaluations were performed by a gynecologist who had oncology experience.

\section{Statistical Analyses}

The statistical analyses were performed by SPSS (Statistical Package for the Social Sciences) 13 (SPSS Inc., Chicago, IL, USA) programme. Quantitative data were expressed as "standard deviation \pm mean" and categorical data were expressed as percentages. One way ANOVA test was used to determine the significance of difference between the groups regarding age, gravidy, parity, number of partners, and age at first coitus. Chi-square test was used to compare the categorical data and Student's T-test was used to compare the continuous data between all groups. The differences in proportions between groups were compared by using Tukey test, where appropriate. Chi square or Fisher's exact test were used to compare categorical data. Age, gravidy, parity, number of partners and age at first coitus were compared by using Kruskal Wallis and Mann-Whitney U tests. A P value of $<0.05$ was considered statistically significant.

\section{RESULTS}

Among the 86 patients who were included in the study, 55 (63.9\%) were diagnosed as ASCUS, three (3.4\%) were diagnosed as AGC, 19 (23\%) were diagnosed as LSIL and nine (10.4\%) were diagnosed as H-SIL. AGC patients were not evaluated inside the study due to the low number of subjects. There was not any statistically significant difference between the groups regarding demographic parameters like age, gravidy, parity, number of sexual partners, presence of high risk HPV and smoking status; except age at first coitus and pathological colposcopy findings (Table I). Age at first coitus was significantly higher in L-SIL patients than ASCUS patients (25(4.4 vs. 23(3.4, respectively, $\mathrm{p}<0.01$ ). Besides, the youngest group at first coitus was ASCUS patients $(p<0.01)$. Pathological colposcopy findings were significantly higher in H-SIL patients than ASCUS patients ( $90 \%$ vs. $40 \%$, respectively, $p<0.01$ ). Similarly, there was a statistically significant difference between the groups H-SIL and L-SIL regarding pathological colposcopy findings ( $90 \%$ vs. $58 \%$, respectively, $\mathrm{p}<0.05$ ). However, 
there were no statistically significant differences in between the groups regarding presence of high risk HPV (11\%, $5 \%$, and $33 \%$, respectively). Additionally, there were similar smoking rates for all of the groups $(33 \%, 37 \%$, and $33 \%$, respectively).

Table 1: Comparison of the groups regarding the demographic parameters.

\begin{tabular}{|c|c|c|c|c|c|c|}
\hline & $\begin{array}{l}\text { ASCUS } \\
(n=55)\end{array}$ & $\begin{array}{l}\text { L-SIL } \\
(n=19)\end{array}$ & $\begin{array}{l}\text { H-SIL } \\
(n=9)\end{array}$ & $\begin{array}{l}p \\
P^{1}\end{array}$ & $P^{2}$ & $P^{3}$ \\
\hline Age (years) & $37 \pm 9.2$ & $33 \pm 8.8$ & $36 \pm 7.3$ & NS & NS & NS \\
\hline Gravidy (n) & $2 \pm 1.6$ & $1 \pm 1.1$ & $2 \pm 0.3$ & NS & NS & NS \\
\hline Parity (n) & $1 \pm 1.3$ & $1 \pm 1.05$ & $1.5 \pm 0.8$ & NS & NS & NS \\
\hline $\begin{array}{l}\text { No. of sexual } \\
\text { partners (n) }\end{array}$ & $1 \pm 1.3$ & $1 \pm 0.3$ & $1 \pm 0.0$ & NS & NS & NS \\
\hline $\begin{array}{l}\text { Age at first coitus } \\
\text { (years) }\end{array}$ & $23 \pm 3.4$ & $25 \pm 4.4$ & $23 \pm 5.6$ & NS & NS & $<0.01$ \\
\hline Pathological colposcop & & & & & & \\
\hline findings (\%) & 40 & 58 & 90 & $<0.05$ & NS & NS \\
\hline Oncogenic HPV (\%) & & 5 & 33 & NS & NS & NS \\
\hline Smoking (\%) & 33 & 37 & 33 & NS & NS & NS \\
\hline
\end{tabular}

Note: H-SIL: high grade cervical intraepithelial lesion; ASCUS: atypical squamous cells of undetermined significance; L-SIL: low grade cervical intraepithelial lesion; HPV: Human Papilloma Virus; NS: not significant $P^{I}$ : comparison of H-SIL and ASCUS groups

$P^{2}$ : comparison of H-SIL and L-SIL groups

$P^{3}$ : compairson of ASCUS and L-SIL groups

Among the pathologic examination of 55 ASCUS patients there were $36(64.65 \%)$ chronic cervisitis, 11 (20\%) CIN I, five (9\%) CIN II, two (3.6\%) CIN III and one $(1.8 \%)$ microinvasive squamous cell cancer patients. The pathological results for three AGC patients were two (66.6\%) chronic cervisitis and one (33.3\%) CIN II. Fourteen (73.6\%) CIN I and five (26.3\%) chronic cervisitis were defined at the pathological examination of 19 L-SIL patients. However, three (33.3\%) CIN I, two (22.2\%) CIN II, two (22.2\%) CIN III, one (11.1\%) chronic cervisitis and one $(11.1 \%)$ microinvasive squamous cell cancer were defined at the pathological examination of $9 \mathrm{H}-\mathrm{SIL}$ patients (Table II).

Table II: Comparison of abnormal Pap smear test results with biopsy results.

\begin{tabular}{lllll}
\hline $\mathbf{n}=\mathbf{8 6}$ & $\begin{array}{l}\text { ASCUS } \\
\mathbf{n = 5 5}(\%)\end{array}$ & $\begin{array}{l}\text { AGC } \\
\mathbf{n = 3}(\%)\end{array}$ & $\begin{array}{l}\text { L-SIL } \\
\mathbf{n = 1 9}(\%)\end{array}$ & $\begin{array}{l}\text { H-SIL } \\
\mathbf{n}=\mathbf{9}(\%)\end{array}$ \\
\hline Chronic cervisitis & $36(\% 65.5)$ & $2(\% 66.6)$ & $14(\% 73.6)$ & $1(\% 11.1)$ \\
CIN I & $11(\% 20)$ & - & $5(\% 26.3)$ & $3(\% 33.3)$ \\
CIN II & $5(\% 9)$ & $1(\% 33.3)$ & - & $2(\% 22.2)$ \\
CIN III & $2(\% 3.6)$ & - & - & $2(\% 22.2)$ \\
Cervix cancer & $1(\% 1.8)$ & - & - & $1(\% 11.1)$ \\
\hline
\end{tabular}

According to the results of this study, the pap-smear diagnosis of ASCUS was up-graded by histopathological examination in $34.5 \%$ of patients and not changed in $65.5 \%$. Among the L-SIL patients $73.6 \%$ were downgraded by histopathological examination and the degree of diagnosis was not changed in $26.3 \%$. However, histopathological examination of H-SIL patients upgraded the diagnosis in $11.1 \%$ of cases and the diagnosis was chronic cervisitis or CIN I in $44.4 \%$ of the patients (Table III).

Table III: Changes in Pap smear diagnoses after pathologic examination.

\begin{tabular}{llll}
\hline & ASCUS & L-SIL & H-SIL \\
\hline Up-graded (\%) & 34.5 & - & 11.1 \\
Not changed (\%) & 65.5 & 26.3 & 44.4 \\
Down-graded (\%) & - & 73.6 & 44.4 \\
\hline
\end{tabular}

We also defined the diagnostic accuracy of Pap smear test by comparing with biopsy results. The sensitivity and specificity of Pap smear were $65.2 \%$ and $42.8 \%$ respectively for the diagnosis of ASCUS; $26.3 \%$ and $79.1 \%$ respectively for the diagnosis of L-SIL; and $35.7 \%$ and $94.4 \%$ for the diagnosis of H-SIL (Table IV).

Table IV: Evaluation of the adequacy of cervical smear test by comparing it with histopathological results.

\begin{tabular}{llll}
\hline $\mathbf{n = 8 6}$ & $\begin{array}{l}\text { ASCUS } \\
(\mathbf{n = 5 5})\end{array}$ & $\begin{array}{l}\text { L-SIL } \\
(\mathbf{n}=\mathbf{1 9})\end{array}$ & $\begin{array}{l}\text { H-S I L } \\
(\mathbf{n}=\mathbf{9})\end{array}$ \\
\hline Sensitivity(\%) & 65.2 & 26.3 & 35.7 \\
Specificity(\%) & 42.8 & 79.1 & 94.4 \\
PPD(\%) & 85.45 & 26.3 & 55.5 \\
NPD(\%) & 19.35 & 79.1 & 88.3 \\
False positive rate(\%) & 57.2 & 20.9 & 5.6 \\
False negative rate(\%) & 34.8 & 73.7 & 64.3 \\
\hline
\end{tabular}

Note: ASCUS: atypical squamous cells of undetermined significance; L-SIL: low grade cervical intraepithelial lesion; H-SIL: high grade cervical intraepithelial lesion; PPV: pozitive predictive value; $N P V$ : negatie predictive value. 


\section{DISCUSSION}

The most common pathological Pap smear test result was ASCUS (63.9\%). The next common results were L-SIL (22.1\%) and H-SIL (10.4\%), respectively. According to the histopathological examination the incidences of CIN I, CIN II, and CIN III were 22.1\%, $9.3 \%$ and $4.6 \%$, respectively. There was not any significant difference between the groups regarding age, parity, smoking status, and presence of high risk HPV. The pap-smear diagnosis of ASCUS was upgraded to CIN or cancer by histopathological examination in $34.5 \%$ of patients and not changed in $65.5 \%$. Among the L-SIL patients $73.6 \%$ were downgraded by histopathological examination and the degree of diagnosis was not changed in $26.3 \%$. Histopathological examination of H-SIL patients upgraded the diagnosis to cancer in $11.1 \%$ of cases and the diagnosis was chronic cervisitis or CIN I in $44.4 \%$ of the patients. However, $44.4 \%$ of H-SIL patients were diagnosed as CIN II or CIN III by histopathological examination.

The management strategies are clear for high grade lesions determined by screening for cervix cancer. After two years of follow-up Castle et al. reported 8-9\% CIN III in $411 \mathrm{H}$-SIL patients who were enrolled from ASCUS and L-SIL Triage Study (ALTS) in which the patients were divided into three arms: colposcopy, HPV testing and conservative management ${ }^{(11)}$. The sensitivity for CIN diagnosis were $53 \%, 72 \%$ and $54 \%$ in the arms of colposcopy, HPV testing and conservative management respectively. The results were concluded as HPV testing was as sensitive as colposcopy for CIN determination. However, repeat cytology had enough sensitivity while the cut-off was determined as ASCUS. But, in that situation patients needed two more visits and the necessity for colposcopy was more than HPV testing arm ${ }^{(11)}$. Similarly, in another study including 85 patients with cytologic/histologic abnormalities and 178 patients with normal smear test results, high risk HPVDNA was determined in $54.8 \%$ of H-SIL patients, $25 \%$ of L-SIL patients and 5\% of patients with normal cytology(12). In two different studies, HPV-DNA was determined in 35\% (65.8\% high risk HPV) and 42.9\% of patients with abnormal cytology, respectively. In both of the studies the authors concluded necessity of HPVDNA testing for screening of cervix cancer $(13,14)$. Branca et al. reported that the most common cytological abnormalities in repeated smear tests were ASCUS (37\%), L-SIL (26\%) and H-SIL (4.9\%), respectively (15). According to the punch biopsy results $49 \%$ had CIN I, 5.6\% had CIN II and 17\% had CIN III. High grade colposcopy findings were associated with $\mathrm{H}$ SIL Pap smear result and presence of HPV. H-SIL result, HPV presence and high grade colposcopy findings were defined as the most effective predictors of CIN III ${ }^{(15)}$. According to the results of the present study, H-SIL patients hadmore more high risk HPV (not statistically significant) and pathological colposcopy findings than low grade lesions. However, increased presence of high risk HPV (one in every three patient) does not seem to be distinguishing for H-SIL. Hence, regarding the increased incidence of pathological colposcopy findings and the lower chance of having a low grade lesion, colposcopy guided biopsy would be the best choice for H-SIL patients.

Although the management protocols of high grade lesions like H-SIL and cancer are standardizied, there's still controversy about the management of low grade lesions like ASCUS and L-SIL. There are a few articles comparing these methods in the literature. According to ALTS colposcopy is the best choice for L-SIL patients ${ }^{(16)}$. According to the results of ALTS cytology alone determines $84.5 \%$ of CIN and cancer patients, however, cytology and colposcopy determines $96.4 \%$ (16). Also, in ALTS it's concluded that follow-up with pap smear tests would be the best choice for ASCUS patients $(17)$.

Flannelly et al. randomized patients with low grade abnormal cytology to follow-up with smear test and immediate colposcopy arms ${ }^{(18)}$. The frequency of CIN II or worse was somewhat higher in the group offered immediate colposcopy than in the follow-up patients. Shafi et al. also evaluated patients with low grade cytological abnormalities in a randomized controlled $\operatorname{trial}^{(19)}$. However, they observed no difference between the proportions with CIN II or worse at immediate colposcopy or after 24 months of cytological followup. According to the results of the trial of management of borderline and other low grade abnormal smears (TOMBOLA) which is the most extended costeffectiveness analysis on the management of low grade cervical intraepithelial lesions, immediate colposcopy and follow-up have comparable results ${ }^{(20)}$. In our study sensitivity of cytology and colposcopy or colposcopy and HPV-DNA testing could not evaluated, however 
possibility of positive results were concluded to be low for ASCUS and L-SIL patients. Hence, follow-up with Pap smear test would be appropriate for ASCUS and L-SIL patients instead of tests which are costly, invasive and have less possibility to define a positive result. However, according to the results of this study, $1 / 3$ of ASCUS diagnoses are up-graded by histopathologic examination. So, we have to be sure about patient compliance. In patients with poor compliance, it would be better to perform HPV-DNA testing and colposcopic examination.

In conclusion, according to the results of this study, the management of patients with ASCUS and L-SIL should be follow-up with Pap smear test. The management of patients with H-SIL should be colposcopy guided biopsy. However, there needs to be more randomized trials to assess the contribution of high risk HPV-DNA testing to the management of patients with abnormal cytology.

\section{REFERENCES}

1. Jones BA, Davey DD. Quality management in gynecologic cytology using interlaboratory comparison. Arch Pathol Lab Med 2000; 124 (5): 672- 81.

2. Peto J, Gilham C, Fletcher O, Matthews FE. The cervical cancer epidemic that screening has prevented in the UK. Lancet 2004; 364 (9430): 249- 56.

3. Liu S, Semenciw R, Probert A, Mao Y. Cervical cancer in Canada: changing patterns in incidence and mortality. Int $\mathrm{J}$ Gynecol Cancer 2001; 11 (1): 24- 31.

4. Taylor RJ, Morrell SL, Mamoon HA, Wain GV. Effects of screening on cervical cancer incidence and mortality in New South Wales implied by influences of period of diagnosis and birth cohort. J Epidemiol Community Health 2001; 55 (11): 782- 8

5. Walsh JME. Cervical cancer: developments in screening and evaluation of the abnormal Pap smear. West J Med 1998; 169 (5): 304- 10 .

6. Kurman RJ, Henson DE, Herbst AL, Noller KL, Schiffman MH for the 1992 National Cancer Institute Workshop. Interim guidelines for management of abnormal cervical cytology. JAMA 1994; 271 (23): 1866- 9.

7. The Bethesda System for reporting cervical/vaginal cytological diagnoses: revised after the second National Cancer Institute Workshop, April 29- 30, 1991. Acta Cytol. 1993; 37 (2): 115-24.

8. Covell JI, Wilbur DC, Guidos B, Lee KR, Chhieng DC, Mody
DR. Epithelial Abnormalities: Glandular. In: The Bethesda System for Reporting Cervical Cytology: deinitions, criteria and explanatory notes. Solomon D, Nayar R, eds. Second edition, New York: Springer Science + Business Media, Inc.; 2004. P. 123- 56 .

9. Davey DD, Woodhouse S, Styer P, Stastny J, Mody D. Atypical epithelial cells and specimen adequacy: current laboratory practices of participants in the College of American Pathologists Interlaboratory Comparison Program in Cervicovaginal Cytology. Arch Pathol Lab Med. 2000; 124 (2): 20311.

10. Schiffman M, Solomon D. Findings to date from the ASCUSLSIL triage study (ALTS). Arch Pathol Lab Med. 2003; 127 (8): 946- 9 .

11. Castle PE, Cox JT, Schiffman M, Wheeler CM, Solomon D. Factors influencing histologic confirmation of high-grade squamous intraepithelial lesion cytology. Obstet Gynecol. 2008; 112 (3): 637- 45.

12. Yetimalar H, Köksal A, İnceoğlu M, Kasap B. Premalign ve malign servikal lezyonlu hastalarda HPV enfeksiyonu. TJOD Derg 2009; 6 (4): 273-8.

13. Ergünay K, Misirlioglu M, Firat $\mathrm{P}$, Tuncer ZS, Tuncer S, Yildiz I, Ustaçelebi S. Detection and typing of human papilloma virus by polymerase chain reaction and hybridization assay in cervical samples with cytological abnormalities. Mikrobiyol Bul 2008; 42(2): 273- 82 .

14. Öztürk S, Kaleli I, Kaleli B, Bir F. Investigation of human papillomavirus DNA in cervical specimens by hybrid capture assay. Mikrobiyol Bul 2004; 38(3): 223- 32.

15. Branca M, Ciotti M, Santini D, Di Bonito L, Giorgi C, Benedetto A, Paba P, Favalli C, Costa S, Agarossi Alderisio M, Syrjänen K. p16 (INK4A) expression is related to grade of CIN and high-risk human papillomavirus but does not predict virus clearance after conization or disease outcome. Int J Gynecol Pathol 2004; 23 (4): 354- 65.

16. ALTS Group. A randomized trial on the management of lowgrade squamous intraepithelial lesion cytology interpretations. AmJObstet Gynecol 2003; 188 (6): 1393- 400.

17. ALTS Group. Results of a randomized trial on the management of cytology interpretations of atypical squamous cells of undetermined significance. Am J Obstet Gynecol 2003; 188 (6): $1383-92$

18. Flannelly G, Anderson D, Kitchener HC, Mann EMF, Campbell M, Fisher P, et al. Management of women with mild and moderate cervical dyskaryosis. BMJ 1994; 308 (6941): 1399- 403.

19. Shafi MI, Luesley DM, Jordan JA, Dunn JA, Rollason TP, Yates M. Randomised trial of immediate versus deferred 
treatment strategies for the management of minor cervical cytological abnormalities. Br J Obstet Gynaecol 1997; 104 (5): 590- 4.
20. TOMBOLA Group. Options for managing low-grade cervical abnormalities detected at screening cost effectiveness study. BMJ 2009; 339: b2549. doi: 10.1136/bmj.b2549. 